\title{
Expression and copy number analysis of TRPSI, EIF3S3 and MYC genes in breast and prostate cancer
}

\author{
KJ Savinainen', MJ Linja', OR Saramäki', TLJ Tammela², GTG Chang ${ }^{3}$, AO Brinkmann ${ }^{3}$ and T Visakorpi*, \\ 'Cancer Genetics, Institute of Medical Technology, University of Tampere and Tampere University Hospital, FIN-330/4 Tampere, Finland; ${ }^{2}$ Department \\ of Urology, University of Tampere and Tampere University Hospital, FIN-330 4 Tampere, Finland; ${ }^{3}$ Department of Reproduction and Development, \\ Erasmus MC, 3000 DR Rotterdam, The Netherlands
}

\begin{abstract}
The long arm of chromosome 8 is one of the most common regions of amplification in cancers of several organs, especially carcinomas of the breast and prostate. TRPSI, MYC and EIF3S3 genes are located in one of the minimal regions of amplification, $8 q 23-q 24$, and have been suggested to be the target genes of the amplification. Here, our goal was to study copy number and expression of the three genes in order to investigate the significance of the genes in breast and prostate cancer. By using fluorescence in situ hybridisation (FISH), we first found that TRPSI and EIF3S3 were amplified together in about one-third of hormone-refractory prostate carcinomas. Next, we analysed the mRNA expression of the three genes by real-time quantitative RT-PCR and the gene copy number by FISH in six breast and five prostate cancer cell lines. Breast cancer cell line, SK-Br-3, which contained the highest copy number of all three genes, showed overexpression of only EIF3S3. Finally, the expression levels of TRPSI, EIF3S3 and MYC were measured in freshly frozen clinical samples of benign prostate hyperplasia (BPH), as well as untreated and hormone-refractory prostate carcinoma. The TRPSI and MYC expression levels were similar in all prostate tumour groups, whereas EIF3S3 expression was higher $(P=0.029)$ in prostate carcinomas compared to BPH. The data suggest that the expression of EIF3S3 is increased in prostate cancer, and that one of the mechanisms underlying the overexpression is the amplification of the gene.

British Journal of Cancer (2004) 90, 104 I-1046. doi:I0.1038/sj.bjc.660 I648 www.bjcancer.com

(C) 2004 Cancer Research UK
\end{abstract}

Keywords: prostate cancer; breast cancer; TRPSI; EIF3S3; MYC; overexpression

Molecular cytogenetic analyses, especially comparative genomic hybridisation (CGH), have indicated that gain of the long arm of chromosome $8(8 \mathrm{q})$ is one of the most common chromosomal aberrations in many human malignancies, including breast and prostate carcinomas (Forozan et al, 1997). For example, about $70-90 \%$ of metastatic and/or hormone-refractory prostate carcinomas as well as about $50 \%$ of untreated breast cancers contain gain of $8 \mathrm{q}$ by CGH (Visakorpi et al, 1995; Cher et al, 1996; Tirkkonen et al. 1998; Nupponen et al, 1999). The gain of 8q has also been found to be associated with an aggressive phenotype and poor prognosis in these malignancies (Isola et al, 1995; Alers et al, 2000). Two minimal regions of amplification, $8 \mathrm{q} 21$ and $8 \mathrm{q} 23-\mathrm{q} 24$, have been identified in prostate cancer by CGH analyses (Cher et al, 1996; Nupponen et al, 1998). Several putative target genes, such as MYC, PSCA, EIF3S3 and TRPS1, have been proposed for the amplification of 8q23-24 (Jenkins et al, 1997; Reiter et al, 1998; Nupponen et al, 1999; Chang et al, 2000; Rummukainen et al. 2001). However, the significance of each of these genes in tumorigenesis is unclear.

MYC, located at 8q24.1, is a well characterised oncogene, which is involved in early embryogenesis, control of cell growth, cell differentiation and apoptosis (Giaccia and Denko, 2000). Its

*Correspondence: Dr T Visakorpi; E-mail: tapio.visakorpi@uta.fi Received I October 2003; revised 8 December 2003; accepted 15 December 2003 overexpression or amplification has been found in several cancer types, including breast and prostate cancer (Jenkins et al, 1997; Nupponen et al, 1998; Rummukainen et al, 2001).

We have recently identified two putative target genes for $8 \mathrm{q}$ amplification, EIF3S3 and TRPS1 (alias GC79) both located at 8q23 (Nupponen et al, 1999; Chang et al, 2000). Using suppression subtraction hybridisation (SSH), EIF3S3 was found to be overexpressed in breast cancer cell line SK-Br-3, which contains a highlevel amplification at 8q23-q24 by CGH (Nupponen et al, 1999). Subsequently, it was found that the gene is amplified in about $30-$ $50 \%$ of hormone-refractory, but only in $10-20 \%$ of untreated prostate carcinomas. The amplification of the gene has been found to be associated with high Gleason score (Saramäki et al, 2001). In addition, about $20 \%$ of untreated breast cancers contain amplification of EIF3S3 gene (Nupponen et al, 1999). The EIF3S3 gene encodes for a p40 subunit of eukaryotic translation initiation factor 3 (eIF3). The eIF3 complex plays a central role in the translation initiation pathway by binding to $40 \mathrm{~S}$ ribosomal subunits in the absence of other translational components, and it helps to maintain the $40 \mathrm{~S}$ and $60 \mathrm{~S}$ subunits in a dissociated state (Asano et al, 1997). The function of the p40 subunit itself is, however, not known. It has been suggested that also some other translation initiation factors might be involved in the development of malignancies. For example, the overexpression of EIF4E as well as EIF4G1 has been shown to transform normal cells (De Benedetti and Rhoads, 1990; Fukuchi-Shimogori et al, 1997) and increased expression of EIF4E has been found in breast cancer cell lines 
(Anthony et al, 1996). In addition, a recent cDNA microarray study suggested that upregulation of several genes of translation apparatus is generally involved in metastasis of cancer (Ramaswamy et al, 2003).

TRPS1 was recently found to be more expressed in androgendependent than androgen-independent LNCaP prostate cancer cell lines by differential display analysis (Chang et al, 2000). TRPS1 encodes a zinc-finger GATA-type nuclear protein, which has been implicated in apoptosis. Castration leads to increased expression of TRPS1 in rat ventral prostate (Chang et al, 2000, 2002). Germline mutations in the TRPS1 gene, on the other hand, cause trichorhino-phalangeal syndrome (TRPS) types I and III (Momeni et al, 2000, Lüdecke et al, 2001). In addition, it was reported that xenopus TRPS1 acts as a repressor of the xenopus GATA4 transcription factor (Malik et al, 2001). This suggests that human TRPS1 could be involved in gene regulation of the family of human GATA transcription factors.

In order to evaluate the significance of EIF3S3, MYC, and TRPS1 in breast and prostate cancer, we have analysed the expression and copy number of the three genes in cell lines and tumours using quantitative real-time RT - PCR and fluorescence in situ hybridisation (FISH).

\section{MATERIALS AND METHODS}

\section{Cell lines and tumour samples}

Five prostate cancer cell lines (PC-3, LNCaP, DU145, 22rv1 and NCI-H660) and six breast cancer cell lines (SK-Br-3, ZR75-1, MCF7, MDA436, EFM19 and T47D) were obtained from the American Type Culture Collection (ATCC, Manassas, VA, USA) and cultured under the recommended conditions. Freshly frozen specimens from nine benign prostate hyperplasias (BPH), 35 untreated primary (from 34 prostatectomies and one transurethral resection of the prostate) and 12 locally recurrent hormone-refractory (from transurethral resections of the prostate) prostate carcinomas were obtained from the Tampere University Hospital. The specimens were histologically examined for the presence of more than $60 \%$ of cancerous or hyperplastic tissue using haematoxylin and eosinstained slides. The BPH samples were obtained from prostatectomy specimens from cancer patients. However, the specimens were histologically verified not to contain any cancer cells. The TNM distribution of the untreated cases was pT1N0M0, 2; pT2N0M0, 12; pT2N1M0, 2; pT3N0M0, 13; T4NXM0, 1; TXN0M0, 1 ; TXNXMX, 4. Of the untreated primary carcinomas, 11 were grade I, 16 grade II and seven grade III. Histological grade information was not available for one case. In the hormonerefractory cases, time from the beginning of the therapy to TURP varied from 15 to 60 months. In addition, a tissue microarray (TMA) containing 48 locally recurrent (TURP samples) hormonerefractory formalin-fixed paraffin-embedded prostate carcinomas from the Tampere University Hospital, was constructed according to previously published guidelines (Kononen et al, 1998). The use of clinical tumour material has been approved by the Ethical Committee of the Tampere University Hospital.

\section{RT - PCR}

One to three $20 \mu \mathrm{m}$ frozen sections were cut using a cryotome. The total RNAs were isolated from the sections using Qiagen RNeasy MiniKit (Qiagen Inc., Valencia, CA, USA), and used for the firststrand cDNA synthesis with Superscript ${ }^{\mathrm{TM}}$ II reverse transcriptase and oligo $\mathrm{d}(\mathrm{T})_{12-18}$ primer according to the manufacturer's protocol (Life Technologies, Gaithersburg, MD, USA). For preparing the standard curve, $5 \mu \mathrm{g}$ of total RNA from the prostate cancer cell line LNCaP (ATCC, Manassas, VA, USA) was reverse transcribed as described above. After the first-strand cDNA synthesis, serial dilutions $(1: 5)$ were made to correspond to cDNA transcribed from $500,100,20,4,0.8$ and $0.16 \mathrm{ng}$ of total RNA. Primers for the TRPS1, EIF3S3 and MYC genes were designed with the Primer3 program (available at http://www-genome.wi.mit.edu/cgi-bin/primer3.www.cgi). To avoid amplification of any genomic DNA, the forward and reverse primers for each gene were chosen from different exons. The sizes of the PCR products were designed to be under $400 \mathrm{bp}$ to optimise the RT-PCR measurements. The primer and probe sequences for the genes are given in Table 1 .

The PCR reactions were performed with a LightCycler ${ }^{\mathrm{TM}}$ instrument using the LightCycler - FastStart DNA Master Hybridization Probes Kit (EIF3S3 and MYC) or FastStart DNA Master SYBR Green I Kit (TRPS1) (Roche Diagnostics, Mannheim, Germany). Thermocycling for each reaction was carried out in a final volume of $20 \mu \mathrm{l}$ containing $2 \mu \mathrm{l}$ of cDNA sample (or standard), $4 \mathrm{mM} \mathrm{MgCl}_{2}, 0.5 \mu \mathrm{M}$ of each primer, $0.2 \mu \mathrm{M}$ of fluorescein and $0.4 \mu \mathrm{M}$ LC Red640 labelled probes (or SYBR Green I stain in TRPS1 assay), as well as $1 \times$ ready-to-use reaction mix including Taq DNA polymerase, reaction buffer and dNTP mix. After $10 \mathrm{~min}$ of initial denaturation at $+95^{\circ} \mathrm{C}$, the cycling conditions of 50 cycles consisted of denaturation at $+95^{\circ} \mathrm{C}$ for $1 \mathrm{~s}$ (EIF3S3 and MYC) or $10 \mathrm{~s}$ (TRPS1), annealing at $+58^{\circ} \mathrm{C}$ for $10 \mathrm{~s}$ (EIF3S3 and MYC) or at $+60^{\circ} \mathrm{C}$ for $7 \mathrm{~s}$ (TRPS1) and elongation at $+72^{\circ} \mathrm{C}$ for $10 \mathrm{~s}$ (EIF3S3) or $13 \mathrm{~s}$ (MYC) or $7 \mathrm{~s}$ (TRPS1). After the PCR reaction and fluorescence measurements, fit point method together with background adjustment was used to determine the cycle in which the log-linear signal was distinguished from the background, and that cycle number was used as the crossing-point value. The software produced the standard curve by measuring the crossing point of each standard and plotting them against the logarithmic values of concentrations (Figure 1). The expression levels of TRPS1, EIF3S3 and MYC were normalised by the expression level of the housekeeping gene TATA binding protein (TBP), measured as previously described (Linja et al, 2001). The relative expression was illustrated by dividing the EIF3S3, TRPS1 and MYC values with the TBP value, and multiplying by 10 . TBP was chosen for the reference gene, because there are no known retro-

Table I Primer and probe sequences used in the real-time RT-PCR

\begin{tabular}{|c|c|c|}
\hline Gene & Primer sequences $\left(5^{\prime}-3^{\prime}\right)$ & Hybridization probe sequences $\left(5^{\prime}-3^{\prime}\right)^{*}$ \\
\hline C-MYC & $\begin{array}{l}\text { CCT ACC CTC TCA ACG ACA GC } \\
\text { CGC CTC TTG ACA TTC TCC TC }\end{array}$ & $\begin{array}{l}\text { GCCTCCCTCCACTCGGAAGGACT-Fluorescein } \\
\text { Red640-TCCTGCTGCCAAGAGGGTCAAGTT }\end{array}$ \\
\hline TRPSI & $\begin{array}{l}\text { GTA TCC TGC ATC GGG AGA AA } \\
\text { AGC TTC TGG TAG AGG CCA CA }\end{array}$ & \\
\hline
\end{tabular}

*purchased from Tib Mol Biol, Berlin, Germany. 
A

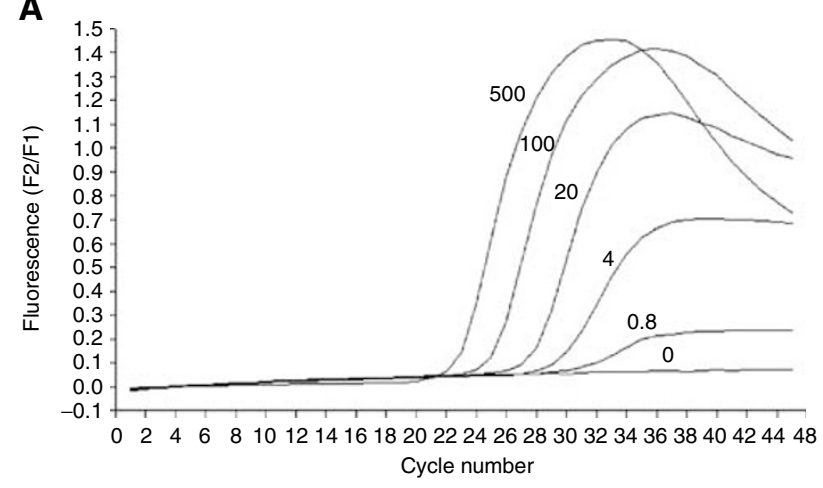

B

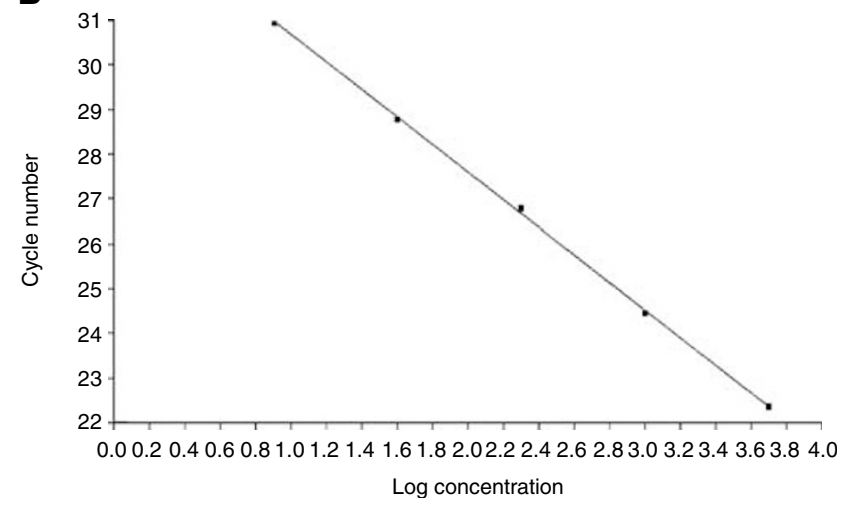

Figure I Standard curve of the MYC expression measurement by realtime RT-PCR. (A) Serially diluted standard corresponding to cDNA transcribed from 500, 100, 20, 4 and $0.8 \mathrm{ng}$ of total RNA. Cycle number is blotted against fluorescent signal obtained in every cycle at the end of the annealing step. (B) Standard curve blotting cycle number at the crossingpoint values of each standard against the logarithmic value of concentration of the standards.

pseudogenes for it and its expression is lower than that of many commonly used abundantly expressed reference genes (Bieche et al, 1999). After the PCR, every sample was also run in $1.2 \%$ agarose gel electrophoresis to ensure that the right size product was amplified in the reaction. Melting curve analysis was also used to evaluate the quality of the PCR reaction for TRPS1.

\section{Fluorescence in situ hybridisation}

Locus-specific PAC probes for human TRPS1 (Chang et al, 2000), EIF3S3 (Nupponen et al, 1999) and MYC (Nupponen et al, 1998) were labelled with digoxigenin-dUTP (Roche Diagnostics), and a pericentromeric probe for chromosome 8 (pJM128) with FITCdUTP (NEN, Boston, MA, USA), by nick translation. The metaphase preparations from the cancer cell lines were prepared using standard techniques. The dual-colour hybridisation was performed essentially as described previously (Hyytinen et al, 1994). Briefly, the slides were denatured in a $70 \%$ formamide/ $2 \times$ SSC solution $\left(\mathrm{pH} \mathrm{7.0)}\right.$ ) at $70^{\circ} \mathrm{C}$ for 3 min and dehydrated in an ascending ethanol series. Hybridisation was performed over two nights at $37^{\circ} \mathrm{C}$. After stringent washes, the slides were stained with antidigoxigenin-rhodamine (Roche Diagnostics) and counterstained with an antifade solution (Vectashied, Vector Laboratories, Burlingame, CA, USA) containing 4,6-diamidino-2-phenylindole (DAPI). The formalin-fixed paraffin-embedded TMAs were pretreated and hybridised as described previously (Saramäki et al, 2001). The FISH signals were scored from nonoverlapping epithelial cells using Olympus BX50 epifluorescence microscope (Tokyo, Japan). Tumours with a tight cluster of signals or at least two-fold higher copy number of the locus-specific probe signals $v s$ centromeric signals or $\geqslant 5$ copies of locus specific probe signals were considered to contain a high-level amplification of either gene. Tumours with three to four copies of the gene signals were considered to have a gain of the gene.

\section{Statistical analyses}

The associations of the gene copy numbers, tumour types, histological grades and clinical stages with expression levels were calculated with nonparametric Kruskal-Wallis and Mann-Whitney $U$-tests. Outliers were detected by using extreme studentised deviate method (ESD).

\section{RESULTS}

\section{TRPS1, EIF3S3 and MYC gene amplification}

Tissue microarrays and FISH were first used to study gene copy number of EIF3S3 and TRPS1 in hormone-refractory prostate carcinomas. High-level amplification ( $\geqslant 5$ copies) of EIF3S3 and TRPS1 was found in 11out of $40(28 \%)$ and 10 out of $36(28 \%)$ of the cases, respectively. The gain (three to four copies) of EIF3S3 and TRPS1 was found in 19 out of $40(48 \%)$ and 18 out of $36(50 \%)$ of the cases, respectively. In the cases of high-level amplification, the genes were always coamplified. The coamplification was also verified by hybridizing differentially-labelled gene specific probes (biotin labelled EIF3S3 probe and AlexaFluor 594 labelled TRPS1 probe) simultaneously to the TMA.

Next, breast and prostate cancer cell lines were analysed for copy numbers of the EIF3S3, MYC and TRPS1 genes. Of the cell lines, the highest copy number of all the genes was found in the breast cancer cell line SK-Br-3, which showed 47 copies of TRPS1 and 21 copies of EIF3S3 and MYC and only one copy of chromosome 8 centromere (Figures 2 and 3). In addition, a high-level amplification (locus/centromere ratio $\geqslant 2$ ) of all three genes was found in MDA436 and PC-3 cancer cell lines. EIF3S3 and MYC were highly amplified also in EFM19 (Figure 3).

\section{Expression of TRPS1, EIF3S3 and MYC}

The standard curves in the real-time quantitative RT-PCR assay showed wide dynamic range and the linear relationship between cycle number and fluorescent threshold was strong $\left(r^{2} \sim 1\right)$. In addition to TBP, the expression of $\beta$-actin was measured and used alternatively for normalisation of most of the samples (data not shown). The results were similar with both control genes. Due to the potential problems with the $\beta$-actin retropseudogenes, TBP was chosen for normalisation of the whole material.

Figure 3 illustrates the relative expression of TRPS1, EIF3S3 and MYC in breast and prostate cancer cell lines. In the breast cancer cell line SK-Br-3, which contains the highest copy number of all the three genes investigated, EIF3S3 was the only gene that showed remarkably high-level (three-to 10-fold compared to the other cell lines) overexpression. The relative expression of TRPS1 was highest in ZR75-1, which contains a loss of the gene compared to centromere copy number. Interestingly, in most breast cancer cell lines, the expression of TRPS1 was high compared to the expression levels of EIF3S3 and MYC. The high expression level of TRPS1 in the breast cancer cell lines has also been observed by Northern and Western blot analyses (Chang et al, unpublished).

Figure 4 illustrates the relative expression of TRPS1, EIF3S3 and MYC in BPH $(n=9)$, untreated primary $(n=30$ for TRPS1, $n=35$ for EIF3S3 and MYC) and locally recurrent hormone-refractory ( $n=12$ for TRPS1, $n=11$ for EIF3S3 and MYC) prostate carcinomas. The expression of EIF3S3 was, on average, three-fold higher $(P=0.029)$ in carcinomas than in BPH. There was no difference in the level of expression of EIF3S3 in hormone- 


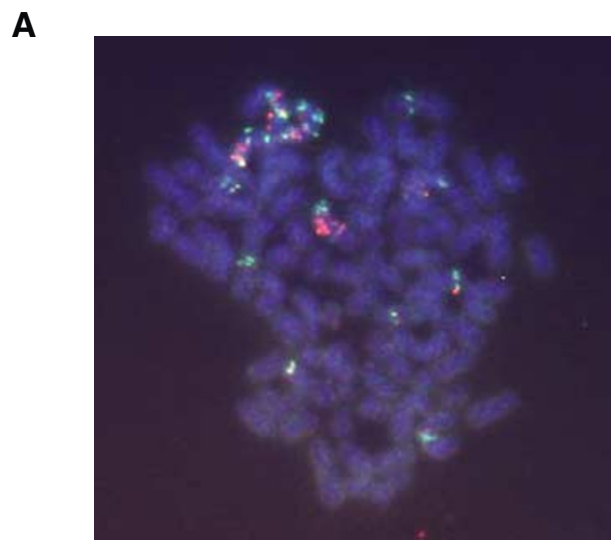

\section{B}

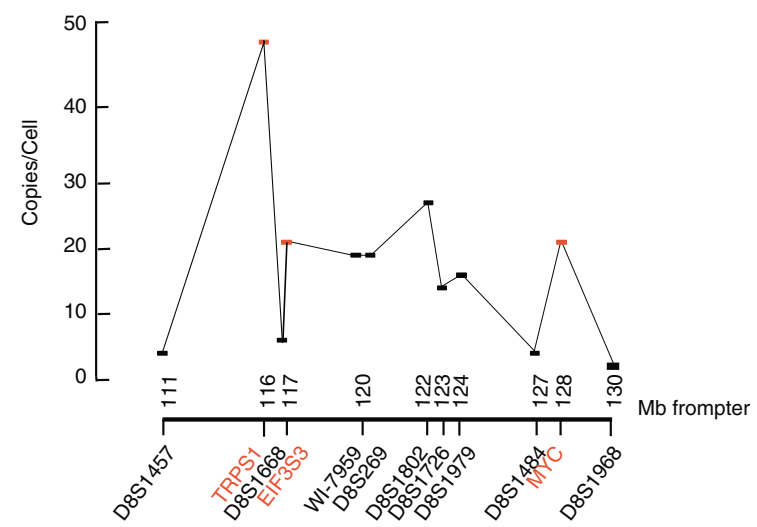

$8 \mathrm{q} 23$

Figure 2 (A) Dual colour FISH with PAC probes for EIF3S3 (green) and TRPSI (red) in metaphase preparation of breast cancer cell line SK-Br-3. Multiple copies of both genes are seen in marker chromosomes. (B) Copy numbers of TRPSI, EIF3S3, MYC and anonymous sequence tag sites (STSs) in SK-Br-3 breast cancer cell line by FISH. The copy numbers of the STSs are from a previous publication (Nupponen et al, 2000). At the bottom, the order and distances in megabases ( $\mathrm{Mb}$ ) of the genes (marked in red) and STSs (marked in black) from the p-telomere (pter) of the chromosome 8 are shown.

refractory and untreated prostate carcinomas. MYC and TRPS1 were expressed in equal levels in $\mathrm{BPH}$, untreated and hormonerefractory tumours. There were no significant associations between histological grade or clinical stage (T3-T4 and/or $\mathrm{N}+$ and/or $\mathrm{M}+v s \mathrm{~T} 1-2 \mathrm{~N} 0 \mathrm{M} 0)$ and the expression of any of the three genes in the untreated tumours.

\section{DISCUSSION}

Several oncogenes are activated by overexpression of the gene and one mechanism of the overexpression is amplification of the gene (Brodeur and Hogarty, 1998). Gain or amplification of chromosome $8 \mathrm{q}$ is one of the most common chromosomal alterations in breast and prostate cancer (Forozan et al, 1997). However, the target gene of the amplification is still unknown. The genes studied here, EIF3S3, TRPS1 and MYC, have been suggested to be putative target genes in 8q23-q24 (Jenkins et al, 1997; Nupponen et al, 1999; Chang et al, 2000). In order to evaluate the significance of these genes in breast and prostate cancer, we analysed both the gene copy numbers as well as the expressions of the three genes.

\section{A}

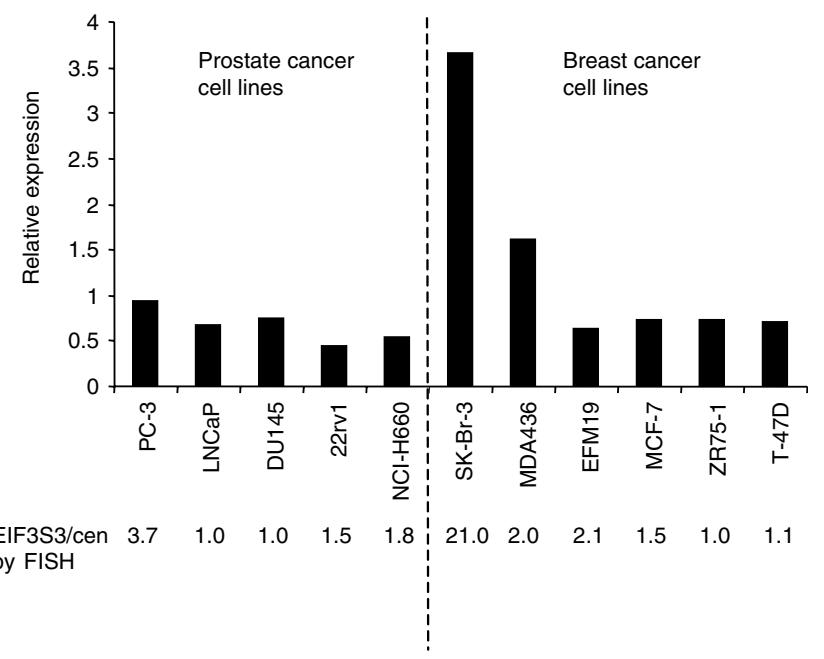

B

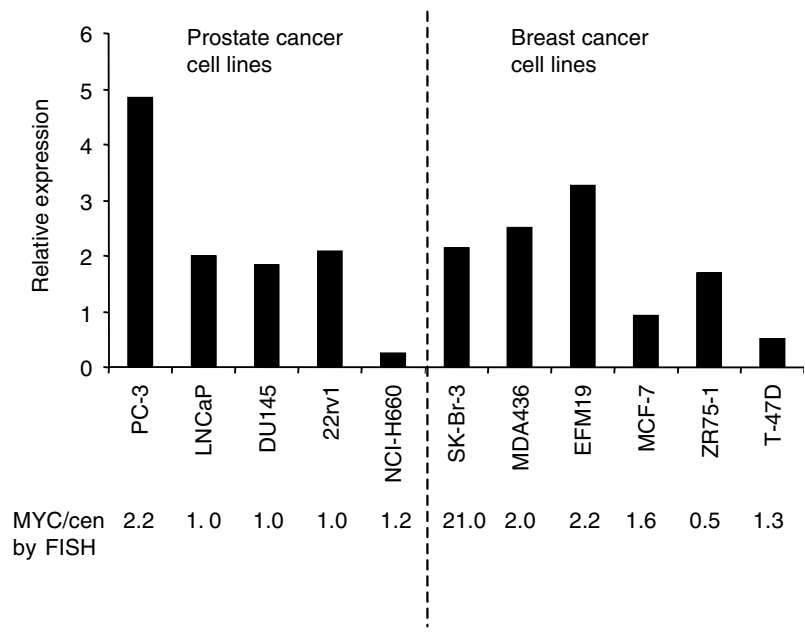

C

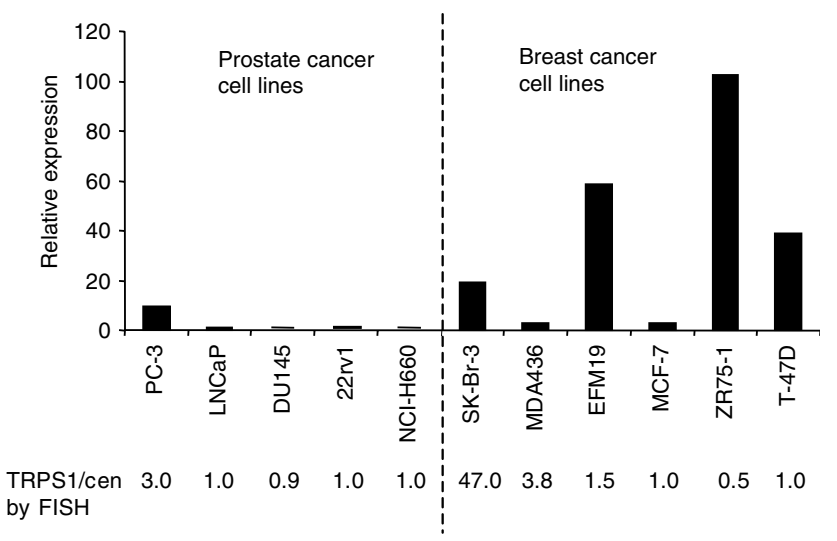

Figure 3 Relative expression and gene copy number of (A) EIF3S3, (B) MYC and (C) TRPSI in prostate and breast cancer cell lines by real-time quantitative RT-PCR and FISH. The relative expression of the genes was calculated by dividing the expression value of the gene of interest with the expression value of housekeeping gene TBP. The relative gene copy number was calculated by dividing the signal copy number of the gene of interest with the signal copy number of chromosome 8 centromere. Of the cell lines, SK-Br-3 showed clearly the highest copy number of all genes. However, only EIF3S3 was overexpressed in the cell line. 
A

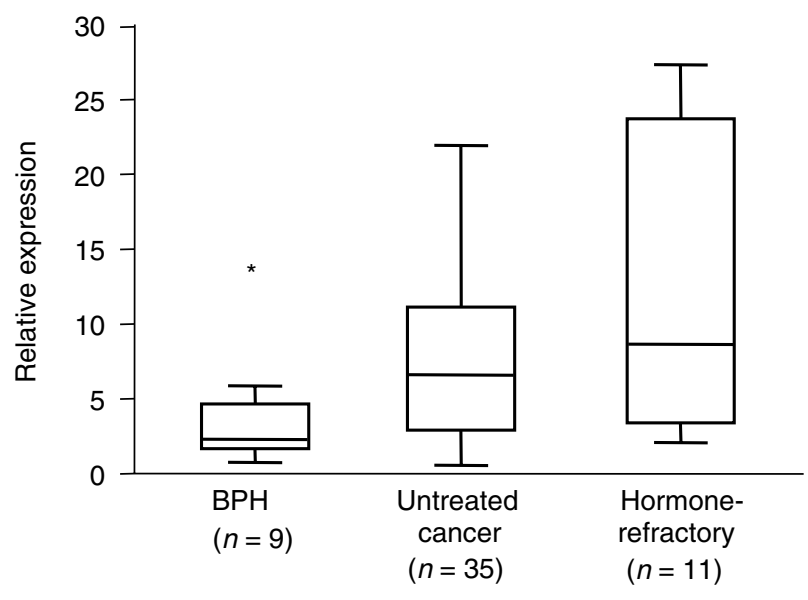

B

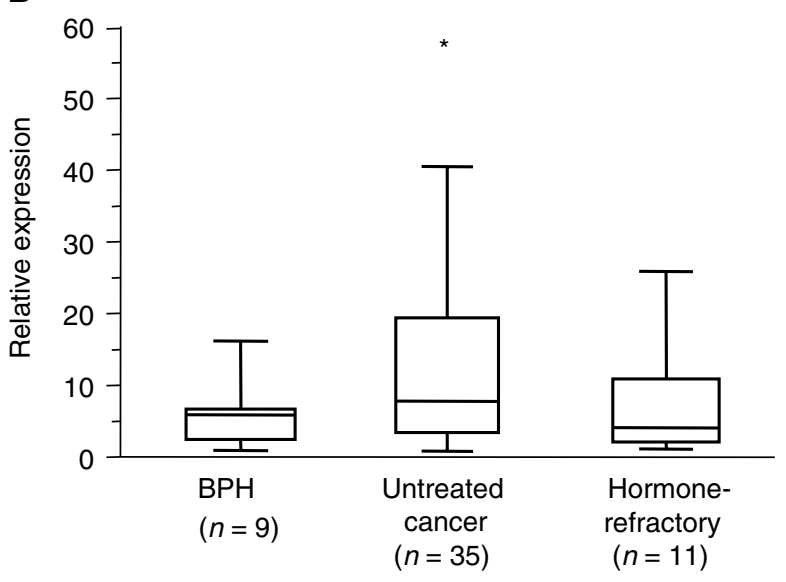

C

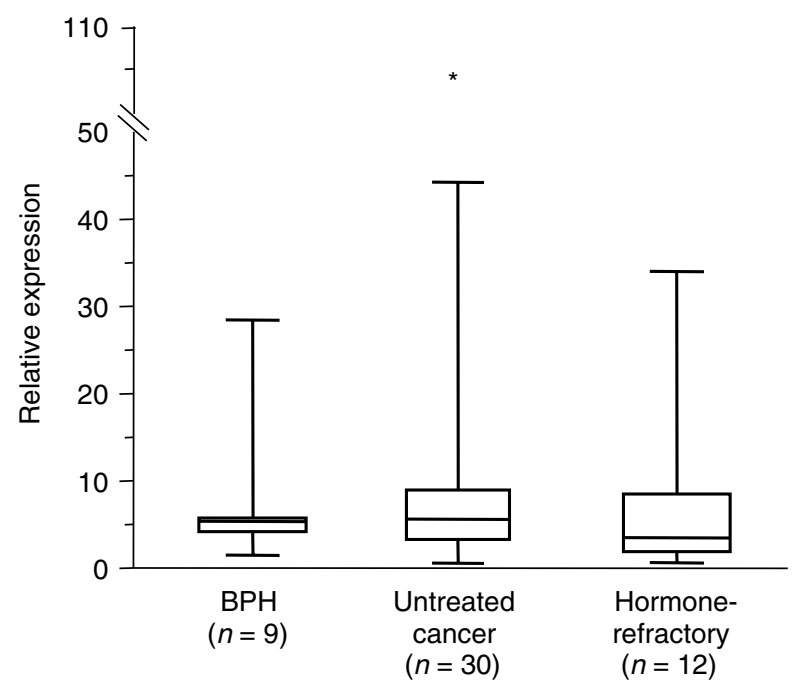

Figure 4 Box and whisker plots displaying the relative expression of $(\mathbf{A})$ ElF3S3, (B) MYC and (C) TRPSI in prostate tumour samples analysed by real-time quantitative RT-PCR. The boxes indicate the area of $50 \%$ of samples, the horizontal line in the boxes indicates median value. The whiskers display the range. Stars depict the outlier values as estimated by extreme studentised deviate method. The expression of EIF3S3 was significantly $(P=0.029)$ higher in carcinomas than in $\mathrm{BPH}$. There were no significant differences in the expression levels of TRPSI and MYC between the tumour groups.
We have previously shown that EIF3S3 and MYC are coamplified in about one-third of the locally recurrent hormonerefractory prostate carcinomas (Saramäki et al, 2001). Now, it was found that also EIF3S3 and TRPS1 are coamplified in about $30 \%$ of the hormone-refractory prostate tumours. The finding that all three genes are commonly coamplified in the hormone-refractory tumours indicates that the size of the amplicon is large. The TRPS1 and EIF3S3 genes are located about 12 and $11 \mathrm{Mb}$ centromeric from MYC, respectively. The large size and the relatively low copy number of the amplicon have previously been implicated also by CGH and FISH studies (Visakorpi et al, 1995; Cher et al, 1996; Nupponen et al, 1998, 2000).

The majority of cancer cell lines have been established from metastatic lesions of cancer. They typically contain more chromosomal alterations than primary tumours, and the aberrations are more confined. For example, amplicons are often smaller and the copy numbers higher making the cell lines more informative than the primary tumours for mapping the amplicons (Kallioniemi et al, 1994). Of the breast and prostate cancer cell lines, however, only SK-Br-3 shows a high-level amplification of two (8q21 and 8q23-24) independent subarm regions by CGH (Kallioniemi et al, 1994; Nupponen et al, 1999). Of the three genes analysed here, TRPS1 showed the highest copy number, about twice as high as for either EIF3S3 or MYC in SK-Br-3. Together with our previous mapping data (Nupponen et al, 2000), the results indicate that SK-Br-3 contains high copy numbers of all the three genes with low copy numbers of the flanking regions (Figure 1B). Thus, the amplicon from TRPS1 to MYC, covering a chromosomal region of about $12 \mathrm{Mb}$, contains, at least, three independent subamplicons in SK-Br-3.

We used real-time quantitative RT - PCR approach to measure the expression of TRPS1, EIF3S3 and MYC. In real-time PCR, the quantification of the template is based on detection of the cycle in which the reaction enters the exponential phase, instead of measuring the amount of end product. Thus, none of the reagents is rate limiting in the reaction at the time of measurement of the fluorescence. Several studies have already shown that real-time RT - PCR is a highly quantitative and reliable method (Bieche et al, 1999; Linja et al, 2001; Savinainen et al, 2002). It is also especially useful in analysis of small tumour samples.

We first analysed the expression of EIF3S3, MYC and TRPS1 in the cell lines. In SK-Br-3, which showed the highest copy number of the genes, the expression of only EIF3S3 was remarkably high. The high-level expression of EIF3S3, shown here by quantitative RT - PCR, confirms our earlier Northern blot data (Nupponen et al, 1999). Surprisingly, the expression of TRPS1, whose copy number was highest of the three genes in SK-Br-3, was lower in SK-Br-3 compared to ZR75-1. The expression of TRPS1 was the highest in ZR75-1, which actually contains a relative loss of the gene. The expression of MYC varied among the cell lines. SK-Br-3 containing the highest copy number of the gene did not show clearly increased expression compared to the other cell lines. The data suggest that of the three genes, EIF3S3 is the most likely target gene of amplification in SK-Br-3.

In the clinical prostate cancer specimens, the level of EIF3S3 expression was significantly $(P=0.029)$ higher in prostate cancer than in BPH. The data are consistent with our previous analyses by semiquantitative mRNA in situ hybridisation, which suggested that EIF3S3 is expressed more in hormone-refractory prostate carcinomas than in BPH (Nupponen et al, 1999). Here, it was found that the expression of EIF3S3 is increased also in untreated prostate cancers. Somewhat surprising, the expression of EIF3S3 was not higher in the hormone-refractory compared to the untreated tumours, despite the fact that hormone-refractory tumours, in general, contain higher frequency of $8 \mathrm{q}$ gain (Visakorpi et al, 1995). The data suggest that EIF3S3 is commonly overexpressed in prostate cancer, and also other mechanisms than gene amplification may lead to the overexpression of the gene. There were no 
significant differences between the expression of either MYC or TRPS1 in BPH, untreated and hormone-refractory carcinomas, suggesting that alterations in the expression of these two genes are not generally involved in the progression of prostate cancer.

In conclusion, the results indicate that overexpression of MYC and TRPS1 are rare in prostate cancer in vivo. In contrast, the expression of EIF3S3 is increased in prostate cancer. One mechanism for the overexpression of EIF3S3 seems to be amplification of the gene as demonstrated by the cell line SK-Br-3. Analyses of the expression levels of EIF3S3 in large clinical materials are now warranted.

\section{ACKNOWLEDGEMENTS}

This work was supported by the Cancer Society of Finland, Finnish Cancer Institute, the Academy of Finland, the Reino Lahtikari Foundation, the Medical Research Fund of Tampere University Hospital, the Sigrid Juselius Foundation, the Finnish Life and Pension Insurance companies and the Dutch Cancer Society (Grant EUR2000-2264). We thank Ms Mariitta Vakkuri, Ms Maarit Ohranen and Ms Heli Lehtonen for technical assistance.

\section{REFERENCES}

Alers JC, Rochat J, Krijtenburg PJ, Hop WC, Kranse R, Rosenberg C, Tanke HJ, Schroder FH, van Dekken H (2000) Identification of genetic markers for prostatic cancer progression. Lab Invest 80: $931-942$

Anthony B, Carter P, De Benedetti A (1996) Overexpression of the protooncogene/translation factor $4 \mathrm{E}$ in breast-carcinoma cell lines. Int $J$ Cancer 65: $858-863$

Asano K, Vornlocher HP, Richter-Cook NJ, Merrick WC, Hinnebusch AG, Hershey JW (1997) Structure of cDNAs encoding human eukaryotic initiation factor 3 subunits. Possible roles in RNA binding and macromolecular assembly. J Biol Chem 272: $27042-27052$

Bieche I, Laurendeau I, Tozlu S, Olivi M, Vidaud D, Lidereau R, Vidaud M (1999) Quantitation of MYC gene expression in sporadic breast tumors with a real-time reverse transcription-PCR assay. Cancer Res 59: 2759-2765

Brodeur GM, Hogarty MD (1998) Gene amplification in human cancers: biological and clinical significance. In The Genetic Basis of Human Cancer, Vogelstein B, Kinzler KW (eds) pp 161-172. New York: McGraw-Hill Companies Inc

Chang GT, Steenbeek M, Schippers E, Blok LJ, van Weerden WM, van Alewijk DC, Eussen BH, van Steenbrugge GJ, Brinkmann AO (2000) Characterization of a zinc-finger protein and its association with apoptosis in prostate cancer cells. J Natl Cancer Inst 92: 1414-1421

Chang GT, van den Bemd GJ, Jhamai M, Brinkmann AO (2002) Structure and function of GC79/TRPS1, a novel androgen-repressible apoptosis gene. Apoptosis 7: 13-21

Cher ML, Bova GS, Moore DH, Small EJ, Carroll PR, Pin SS, Epstein JI, Isaacs WB, Jensen RH (1996) Genetic alterations in untreated metastase and androgen-independent prostate cancer detected by comparative genomic hybridization and allelotyping. Cancer Res 56: $3091-3102$

De Benedetti A, Rhoads RE (1990) Overexpression of eukaryotic protein synthesis initiation factor $4 \mathrm{E}$ in HeLa cells results in aberrant growth and morphology. Proc Natl Acad Sci USA 87: 8212-8216

Forozan F, Karhu R, Kononen J, Kallioniemi A, Kallioniemi OP (1997) Genome screening by comparative genomic hybridization. Trends Genet 13: $405-409$

Fukuchi-Shimogori T, Ishii I, Kashiwagi K, Mashiba H, Ekimoto H, Igarashi K (1997) Malignant transformation by overproduction of translation initiation factor eIF4G. Cancer Res 57: $5041-5044$

Giaccia AJ, Denko NC (2000) Multiple roles for deregulated MYC expression in oncogenesis. In DNA Alterations in Cancer, Ehrlich $\mathrm{M}$ (ed) pp 105-119. Natick: Eaton Publishing

Hyytinen E, Visakorpi T, Kallioniemi A, Kallioniemi OP, Isola JJ (1994) Improved technique for analysis of formalin-fixed, paraffin-embedded tumors by fluorescence in situ hybridization. Cytometry 16: $93-99$

Isola JJ, Kallioniemi OP, Chu LW, Fuqua SA, Hilsenbeck SG, Osborne CK, Waldman FM (1995) Genetic aberrations detected by comparative genomic hybridization predict outcome in node-negative breast cancer. Am J Pathol 147: 905-911

Jenkins RB, Qian J, Lieber MM, Bostwick DG (1997) Detection of c-myc oncogene amplification and chromosomal anomalies in metastatic prostatic carcinoma by fluorescence in situ hybridization. Cancer Res 57: $524-531$

Kallioniemi A, Kallioniemi OP, Piper J, Tanner M, Stokke T, Chen L, Smith HS, Pinkel D, Gray JW, Waldman FM (1994) Detection and mapping of amplified DNA sequences in breast cancer by comparative genomic hybridization. Proc Natl Acad Sci USA 91: 2156-2160

Kononen J, Bubendorf L, Kallioniemi A, Bärlund M, Schraml P, Leighton S, Torhorst J, Mihatsch MJ, Sauter G, Kallioniemi OP (1998) Tissue microarrays for high-throughput molecular profiling of tumor specimens. Nat Med 4: 844-847

Linja MJ, Savinainen KJ, Saramäki OR, Tammela TL, Vessella RL, Visakorpi $\mathrm{T}$ (2001) Amplification and overexpression of androgen receptor gene in hormone-refractory prostate cancer. Cancer Res 61: 3550-3555

Lüdecke HJ, Schaper J, Meinecke P, Momeni P, Gross S, von Holtum D, Hirche H, Abramowicz MJ, Albrecht B, Apacik C, Christen HJ, Claussen U, Devriendt K, Fastnacht E, Forderer A, Friedrich U, Goodship TH, Greiwe M, Hamm H, Hennekam RC, Hinkel GK, Hoeltzenbein M, Kayserili H, Majewski F, Mathieu M, McLeod R, Midro AT, Moog U, Nagai T, Niikawa N, Orstavik KH, Plochl E, Seitz C, Schmidtke J, Tranebjaerg L, Tsukahara M, Wittwer B, Zabel B, Gillessen-Kaesbach G, Horsthemke B (2001) Genotypic and phenotypic spectrum in tricho-rhino-phalangeal syndrome types I and III. Am J Hum Genet 68: $81-91$

Malik TH, Shoichet SA, Latham P, Kroll TG, Peters LL, Shivdasani RA (2001) Transcriptional repression and developmental functions of the atypical vertebrate GATA protein TRPS1. EMBO J 20: 1715-1725

Momeni P, Glockner G, Schmidt O, von Holtum D, Albrecht B, GillessenKaesbach G, Hennekam R, Meinecke P, Zabel B, Rosenthal A Horsthemke B, Ludecke HJ (2000) Mutations in a new gene, encoding a zinc-finger protein, cause tricho-rhino-phalangeal syndrome type I. Nat Genet 24: $71-74$

Nupponen NN, Isola J, Visakorpi T (2000) Mapping the amplification of EIF3S3 in breast and prostate cancer. Genes Chromosomes Cancer 28: $203-210$

Nupponen NN, Kakkola L, Koivisto P, Visakorpi T (1998) Genetic alterations in hormone-refractory recurrent prostate carcinomas. Am J Pathol 153: $141-148$

Nupponen NN, Porkka K, Kakkola L, Tanner M, Persson K, Borg Å, Isola J, Visakorpi T (1999) Amplification and overexpression of p40 subunit of eukaryotic translation initiation factor 3 in breast and prostate cancer. Am J Pathol 154: 1777-1783

Ramaswamy S, Ross KN, Lander ES, Golub TR (2003) A molecular signature of metastasis in primary solid tumors. Nat Genet 33: 49-54

Reiter RE, Gu Z, Watabe T, Thomas G, Szigeti K, Davis E, Wahl M, Nisitani S, Yamashiro J, Le Beau MM, Loda M, Witte ON (1998) Prostate stem cell antigen: a cell surface marker overexpressed in prostate cancer. Proc Natl Acad Sci USA 95: 1735-1740

Rummukainen JK, Salminen T, Lundin J, Joensuu H, Isola JJ (2001) Amplification of c-myc oncogene by chromogenic and fluorescence in situ hybridization in archival breast cancer tissue array samples. Lab Invest 81: $1545-1551$

Saramäki O, Willi N, Bratt O, Gasser TC, Koivisto P, Nupponen NN, Bubendorf L, Visakorpi T (2001) Amplification of EIF3S3 gene is associated with advanced stage in prostate cancer. Am J Pathol 159: $2089-2094$

Savinainen KJ, Saramäki OR, Linja MJ, Bratt O, Tammela TL, Isola JJ, Visakorpi T (2002) Expression and gene copy number analysis of ERBB2 oncogene in prostate cancer. Am J Pathol 160: 339-345

Tirkkonen M, Tanner M, Karhu R, Kallioniemi A, Isola J, Kallioniemi OP (1998) Molecular cytogenetics of primary breast cancer by CGH. Genes Chromosomes Cancer 21: 177-184

Visakorpi T, Kallioniemi AH, Syvänen AC, Hyytinen ER, Karhu R, Tammela T, Isola JJ, Kallioniemi OP (1995) Genetic changes in primary and recurrent prostate cancer by comparative genomic hybridization. Cancer Res 55: 342-347 